\title{
Estimasi Penentuan Tingkatan dan Pola Lorong Gua Banyu dan Sekitarnya dengan Menggunakan GIS
}

\author{
Mochammad Ainul Labib', Agung Suprianto ${ }^{12}$ \\ ${ }^{1}$ Mahasiswa Pencinta Alam Jonggring Salaka Universitas Negeri Malang, Malang 65145, Indonesia \\ ${ }^{2}$ Program Studi Pendidikan Geografi, Universitas Kanjuruhan Malang, Malang 65148, Indonesia \\ Email : labib@mail.ugm.ac.id, agung.supriantogeo@gmail.com
}

\begin{abstract}
Abstrak: Karst merupakan bentang lahan hasil proses pelarutan yang telah mengalami karstifikasi. Salah satu bentukannya adalah endokarst, berupa gua. Lorong gua merupakan hasil dari berbagai proses masa lampau, yang menyimpan berbagai fitur yang dihasilkan. Penelitian ini bertujuan untuk mengetahui tingkatan lorong Gua Banyu di Kecamatan Donomulyo, Kabupaten Malang dengan menggunakan Geography Information System (GIS). Metode yang digunakan dalam penelitian ini adalah deskriptif dengan menggunakan analisis bantuan software GIS. Hasil kajian ini menunjukkan bahwa mulut Gua Banyu dan sekitarnya memiliki kenampakan yang mengelompok, dan pola yang berkembang di wilayah kajian berupa curvilinear passage yang didominasi sungai bawah tanah dan bidang perlapisan. Hasil dari tingkatan lorong gua dengan menggunakan ArcGis diketahui dengan adanya empat tingkatan lorong gua yang menunjukkan arah lorong gua ke selatan.
\end{abstract}

Kata Kunci: Estimasi, Tingkatan, Lorong, Gua, GIS,

\section{Pendahuluan}

Daerah selatan Pulau Jawa khusunya Kecamatan Donomulyo Kabupaten Malang memiliki topografi yang berbukit hingga bergelombang. Kondisi demikian merupakan hasil dari proses geomorfologi dan kondisi geologi yang berkembang di daerah tersebut pada masa lampau. Sehingga menghasilkan 2 kenampakan utama yaitu morfologi eksokarst dan endokarst. Berdasarkan Peta Geologi lembar Blitar (Sjarifudin dan Hamidi, 1992), kondisi kajian berada pada Formasi Wonosari. Formasi ini tersusun atas batugamping coral, batu gamping lempungan, batu gamping tufan, batu gamping pasiran, napal, batu lempung hitam bergambut dan kalsirudit. Umur Formasi Wonosari adalah Miosen Tengah-Miosen Akhir.

Daerah yang tersusun dari batu gamping, umumnya memiliki kenampakan adanya guagua di daerah tersebut. Gua sendiri merupakan karakteristik yang khas di morfologi karst, Ko (1997) mengibaratkan gua sebagai buku yang merekam berbagai episode geologi, bioekologi, dan arkeologi yang setiap lorong gua di ibaratkan melintasi halaman yang berisi sejarah. Kenampakan endokarst khusunya gua lebih terjaga dari aktifitas kegiatan manusia, karena gua jarang untuk dimasuki oleh manusia sehingga banyak sejarah geologi didalamnya.

Keterdapatan lorong gua baik vertikal maupun horizontal dapat memberikan gambaran tentang kondisi morfologi endokarst. Kondisi tersebut memberikan tingkatan dalam perkembangan gua. Selain itu, distribusi ketinggian mulut gua dapat digunakan untuk mengetahui tingkatan gua, karena pola tingkatan tersebut merekam jejak yang disebabkan oleh tenaga tektonik maupun evolusi iklim. Terjadinya lorong horizontal pada gua disebabkan oleh faktor hidrologi, pada saat muka airtanah kontak dengan lorong gua (Piccini, 2011).

Aplikasi Geography Information System (GIS) telah digunakan oleh beberapa peneliti untuk menetukan tingkatan lorong gua, antara lain Jacoby et.al (2013; 2011). Setiap ketinggian lorong gua, memiliki tingkatan, baik itu vertikal maupun horizontal. Berdasarkan 
hal tersebut, tujuan dari penelitian ini yaitu untuk menetukan estimasi tingkatan dan pola lorong gua dengan menggunakan GIS dengan melihat bukti-bukti adanya tingkatan lorong gua yang dihubungkan dengan perhitungan secara frekuensi sebagai pembandingnya.

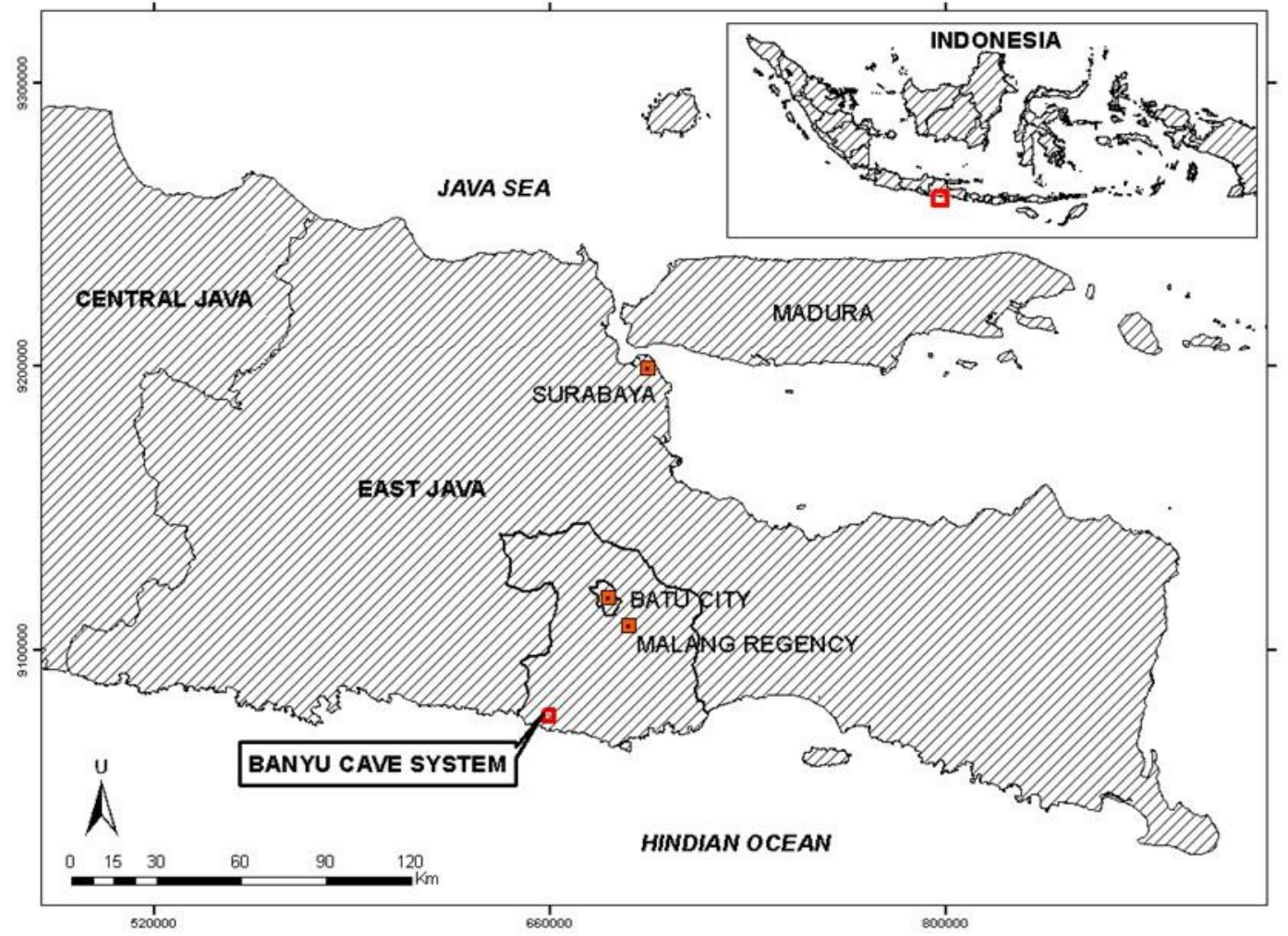

Gambar 1. Daerah Kajian Penelitian

\section{Metode Penelitian}

Gua memiliki ruang yang dapat diukur. Hasil pengukuran atau pemetaan gua umumnya untuk menggambarkan kondisi gua. Metode yang digunakan dalam peneilitian ini adalah deskriptif, yaitu penelitian yang dilakukan untuk mengetahui nilai variabel mandiri, baik satu variabel atau lebih (Sugiyono, 2010). Dalam penelitian ini maka akan dapat dibangun suatu teori yang dapat berfungsi untuk menjelaskan, meramalkan dan mengontrol suatu gejala. Sedangkan, untuk mengakaji lebih dalam dengan menggunakan softwere ArcGis, dimana softwere ini dapat memudahkan untuk mengetahui pola mulut gua, kerapatan lorong, arah kecendrungan lorong, penyimpangan lorong dan estimasi tingkatan lorong gua.

Pola mulut gua menggunakan analisis tetangga terdekat yang digunakan untuk menjelasakan pola persebaran mulut gua dengan mempertimbangkanjarak, indeks kedekatan, $Z$-score, dan P-value. Z-score dan $p$-value adalah ukuran signifikansi statistik yang menunjukkan distribusi data acak. Indeks tetangga terdekat akan digunakan sebagai rasio dari jarak rata-rata data dengan jarak rata-rata standar.Indeks tetangga terdekat dinyatakan sebagai rasio jarak diamati dibagi dengan jarak yang diharapkan. Jarak yang diharapkan adalah jarak rata-rata antara tetangga dalam distribusi acak hipotetis. Jika indeks kurang dari 1; pola menunjukkan pengelompokan; jika indeks lebih besar dari 1; tren kearah dispersi atau persaingan Penggunaan formula analisis tetangga terdekat dalam hal ini menggunakan formula statistik Average Nearest Neighbor atau ANN (Patrick dan Fischer, 1970) sebagai berikut: 


$$
\begin{gathered}
A N N=\frac{\bar{D}_{0}}{\bar{D}_{E}} \\
\bar{D}_{O}=\frac{\sum_{\mathrm{i}=1}^{\mathrm{m}} \mathrm{d}_{\mathrm{i}}}{\mathrm{m}} \\
\bar{D}_{E}=\frac{0.5}{\sqrt{\frac{\mathrm{m}}{\mathrm{A}}}}
\end{gathered}
$$

Di mana Do adalah jarak rata-rata yang diamati antara setiap fitur dan tetangga terdekat mereka, sedangkan DE adalah jarak rata-rata yangdiharapkan untuk fitur dengan pola acak. $\mathrm{M}$ adalah jumlah kejadian, dan A mewakili luas wilayah. Nilai ANN dinyatakan dengan $\mathrm{ANN}=1$ berarti berpola acak (random); ANN $<1$ berarti mengelompok (clustered) ; dan ANN > 1 berarti terpencar (dispersed).

Pengukuran atau pemetaan telah dilakukan di daerah kajian (Impala 2013; Labib, 2016) dengan menghasilkan peta gua yang telah dianalisis secara matematis. Selanjutnya, data yang telah didapatkan itu diolah kembali dengan menggunakan sofwere ArcGis. Data yang utama berasal dari mulut gua sebagai titik kontrol koordinat dan elevasi, selanjutnya data dihubungkan dengan berbagai titik stasiun gua, untuk dianalisis lebih lanjut.

Beberapa penyajian data dengan mengguinakan histrogram, analisis trend, dan analisis normal QQ-plot. Histogram digunakan sebagai tampilan frekuensi mulut gua dan kuluaran pada setiap elevasi. Level gua didenifisikan sebagai kombinasi klasifikasi secara statikal. Selanjutnya untuk mengetahui penyimpangan digunakan analisis normal QQ-plot analisis ini untuk mengetahui daerah mana saja yang menyimpang dari distribusi normalnya. Untuk menunjukan kecenderungan lorong gua menggunakan analisis trend.

\section{Hasil Penelitian}

Pola persebaran lorong gua menggunakan analisis tetangga terdekat menunjukkan nilai rata-rata z-skor dan nilai-p dalam SIG. Penggunaan software ArcGIS 9.3. Dalam hal ini difokuskan pada nilai tetangga terdekat yang terdapat pada Spatial Statistic toolbox. Perhitungan analisis ketetanggaan menunjukkan angka rasio 0,284127 yang artinya menunjukkan pengelompokan gua-gua pada wilayah kajian.Pola pengelompokan ini dihasilkan dari nilai observed mean distance sebesar 4,8616 $\mathrm{m}$ dan nilai expected mean distance sebesar 17,1106 m. Hasil perhitungan statistik menunjukkan nilai z-score sebesar 20,633 dan p-value sebesar 0,0000 yang menunjukkan signifikansi terhadap hipotesis rasio ketetanggaan tersebut. Hal ini dibuktikan dari nilai " $p$ " ( $p$-value) ditunjukkan dengan angka 0,000000 dan nilai z-score dalam Critical Value kurang dari -2,58 ditunjukkan dengan angka $-20,633$.

Setelah mulut gua diketahui memiliki sifat mengelompok, selanjutnya diidentifikasi mengenai gambaran lorong gua yang terbentuk dengan menggabungkan hasil pemetaan gua. Gambar 3 menunjukkan pola yang terbentuk dari lorong gua. Selanjutnya dianalisis kerapatan lorong gua. lorong yang memiliki kerpatan tinggi berada pada percabangan, hal ini terlihat di Gua Sio, Gua Kirek, Gua Kembar, dan Gua Banyu. 

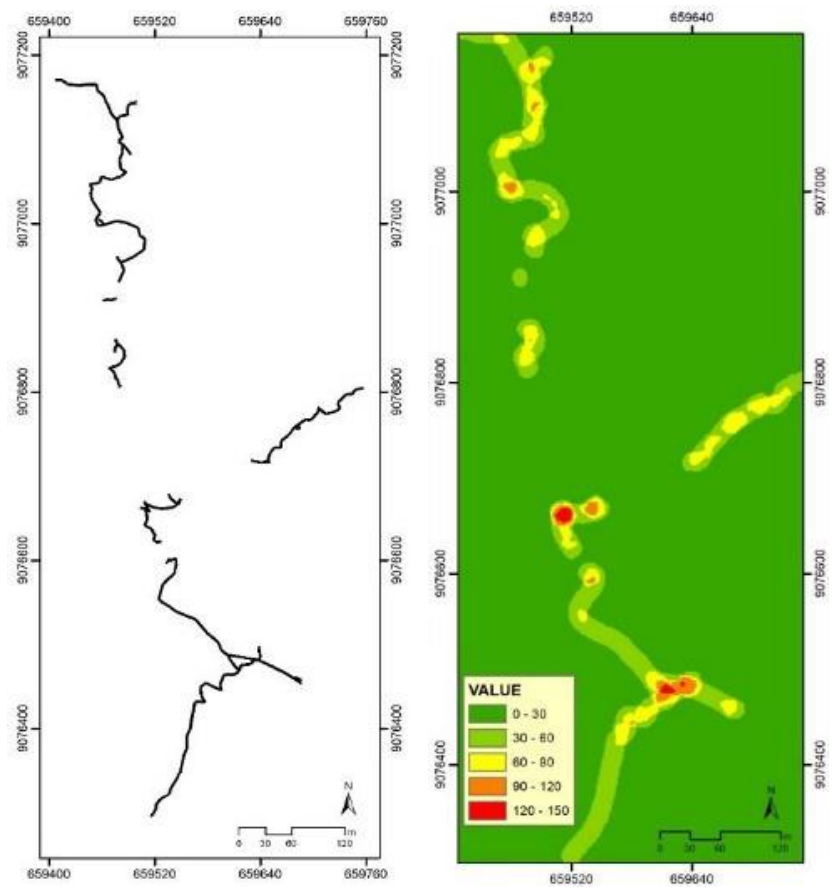

Gambar 2. Analisis Tetangga Terdekat pada Lorong Gua Banyu dan Sekitarnya

Grafik histogram yang dihasilkan pada Gambar 4, dengan mengumpulkan berbagai ketinggian lorong gua, didapatkan bahwa terdapat berbagai level atau tingkatan yang berkembang di Gua Banyu dan Sekitarnya. Ini terlihat dengan adanya 4 tingkatan gua.

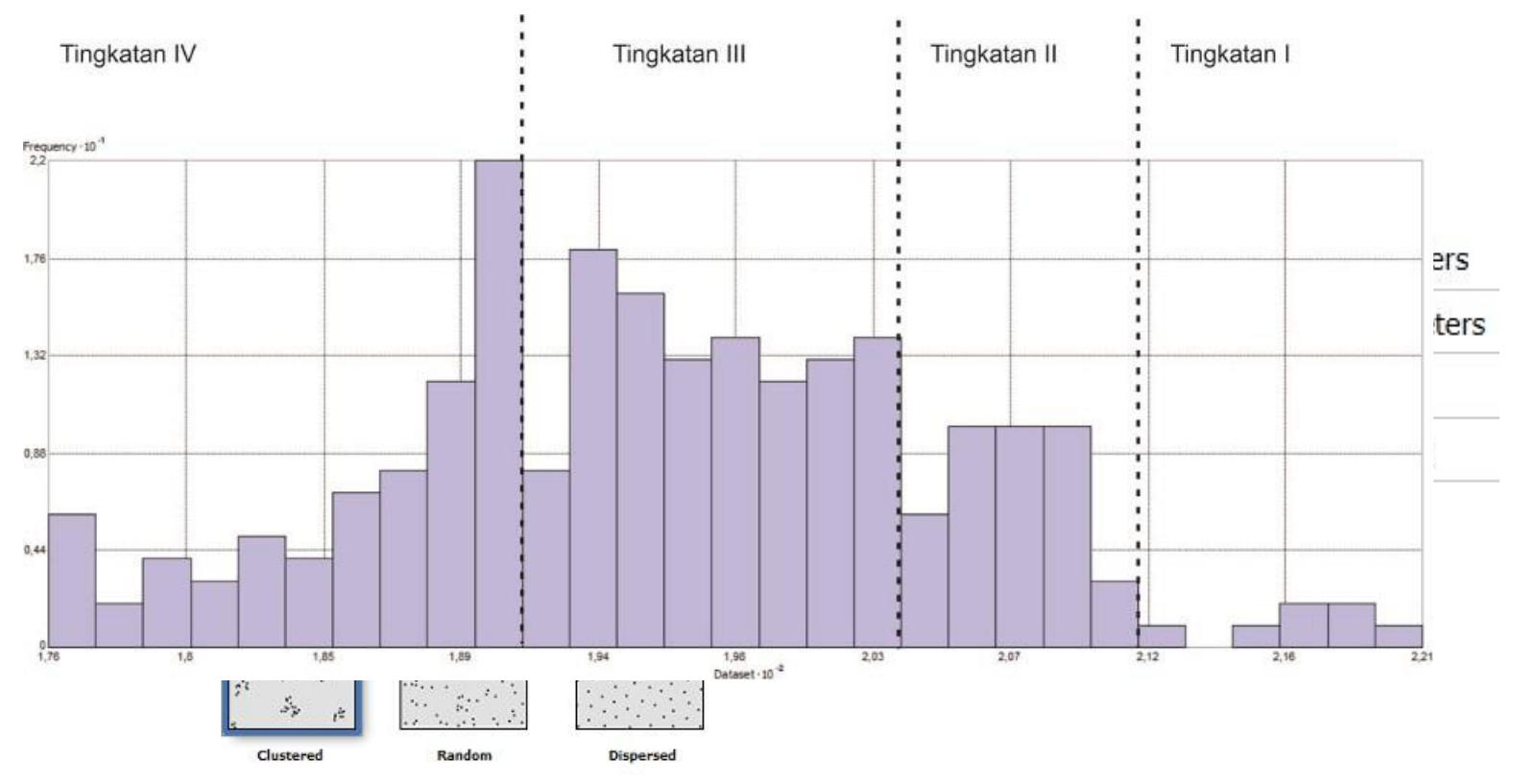

Given the $z$-score of -20.63 , there is a less than $1 \%$ likelihood that this clustered pattern could be the result of random chance.

Gambar 3. Pola dan Kerapatan Lorong Gua Banyu dan Sekitarnya 
Hasil histrogram tersebut dapat diidentifikasi, gua yang berada pada tingkatan yang sama. Tingkatan I terdapat di Gua Sio, yang terletak pada mulut gua sampai terdapatnya chamber. Tingkatan II terlihat pada sungai bawahtanah Gua Sio, dan beberapa mulut gua juga sudah terbentuk, diantarnnya Gua Kirek, Gua Buntet, Gua Maron, dan Gua Megarsari. Pada tingkatan III terdapat pada sungai bawahtanah Gua Kirek, dan pada Gua Sio sudah tidak berada pada tahapan ini. Lorong gua yang lain juga telah berkembang pada tingkatan ini. Tingkatan IV dengan tereksposenya Gua Banyu, namun lorong telah berkembang sebelumnya. Pada tingkatan ini juga terdapat pada Gua Kirek, Gua Buntet, Gua Maron, Gua Kembar, dan Gua Megarsari.

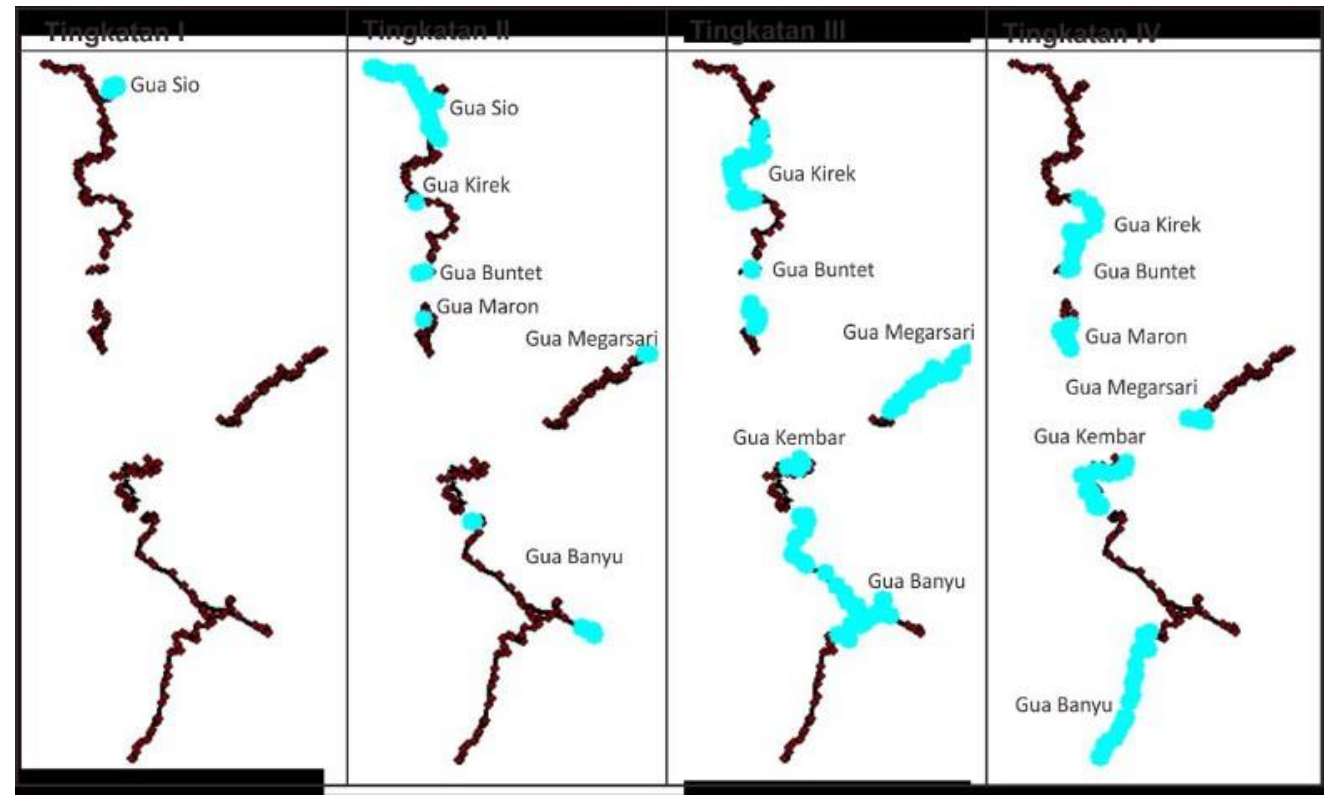

Gambar 5. Tingkatan pada Berbagai Lorong Gua

Berdasarkan grafik analisis kecenderungan (Gambar 5) dapat dilihat bahwa perkembangan lorong gua mengikuti arah aliran sungai bawah tanah. Sumbu x dari trend analysis menunjukan arah timur-barat, sedang sumbu y menunjukan arah utara-selatan. Perkembangan lorong gua secara garis besar mengarah ke arah utara - selatan.

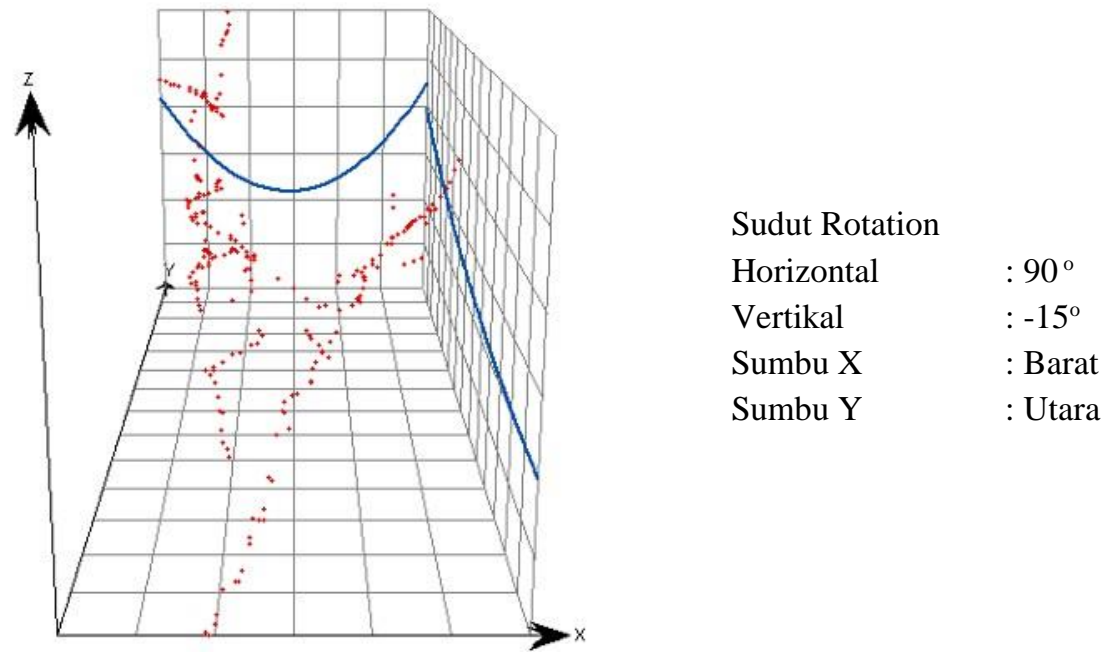

Gambar 5. Analisis Kecenderungan Lorong Gua Banyu dan Sekitarnya 
Gambar 6 menunjukkan penyimpangan yang terjadi pada lorong gua pada setiap tingkatan. (Warna hitam) menunjukkan tingkatan lorong gua yang berapa pa tingkatan I. Pada garis lurus menunjukkan lorong berada di tingkatan yang sama atau mendekati sama. Kondisi menyimpang terdapat pada Gua Sio, Gua Kirek, Gua Kembar dan Gua Banyu.

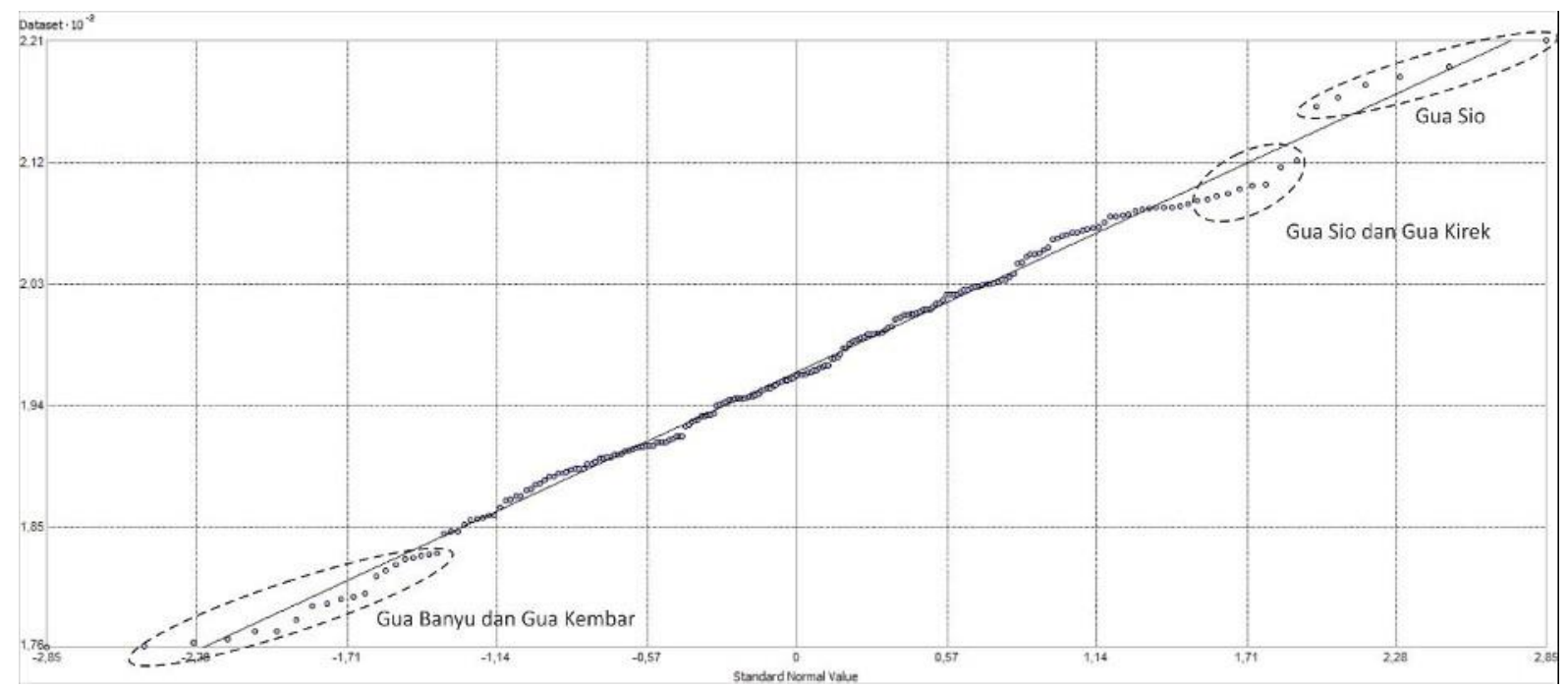

Gambar 6 Analisis Normal QQ-Plot Lorong Gua Banyu dan Sekitarnya

\section{Pembahasan}

Kondisi di daerah Gua Banyu dan sekitarnya memiliki kondisi yang mengelompok, hal ini juga dijelaskan bahwa gua-gua di daerah Donomulyo bersifat mengelompok (Labib, 2016). Pengelompokaan ini dapat menyebakan lorong-lorong gua tersebut dapat saling berhubungan seperti yang dijelakan oleh Ford dan Williams (2007) bahwa gua dapat saling terhubung menjadi sistem perguaan, Hasil kajian Labib menunjukkan (2016) Gua Megarsari 1 dan 2, GuaKembar memiliki keterhubungan, sedangkan Gua banyu dan sekitarnya ada kemungkinan merupakan satu sistem aliran sungai bawahtanah, karena kecendrungan lorong guamengarah ke selatan. Disamping itu, kecendrungan arah lorong juga mengalami penerunan, hal ini juga dapat dimengerti, mengingat regional jawa bagian selatan memiliki kemirngan $10^{\circ}$ (Sjarifudin dan Hamidi, 1992)

Klasifikasi Palmer (1991) menjelaskan bentukan lorong gua yang memiliki bentuk curvilinear passage memiliki kenampakan dengan adanya input dari doline (cekungan tertutup), kondisi lorong gua Banyu dan sekitarnya menunjukkan hal seperti tersebut. Hal ini ditandai dengan adanya kerapatan lorong yang tinggi pada lorong gua yang terdapat pada pertemuan percabangan, pertemuan tersebut merupakan aliran sungai bawahtanah yang saling terhubung dengan yang lain. Selain itu, palmer juga menjelaskan kontrol dominan dalam perkembangan pola tersebut yaitu kontrol bidang perlapisan yang juga berpengaruh pada aliran dalam lorong gua. Bidang perlapisan ini akan membentuk lorong yang horizontal, hal ini menjadikan pada bidang horizontal lorong gua lebih berkembang.

Perkembangan bentang alam karst bagian Jawa selatan mengalami pengangkatan sebanyak 4 kali (Bammelen, 1949). Namun, perkembangan tingkatan lorong Gua Banyu dan sekitarnya membentuk 4 tingkatan, hal ini juga terlihat di daerah Karst Sendang Biru Kabupaten Malang, yang juga berkembang 4 tingkatan (MPA Jonggring Salaka, 2018). Namun secara regional, karst di daerah Donomulyo Kabupaten Malang memiliki 5 tingkatan 
(Labib, 2016), hal ini terlihat pada daerah Kabupaten Pacitan, yang terdapat 5 tingkatan (Tjia, 2013).

\section{Kesimpulan}

Lorong gua merupakan hasil dari berbagai proses masa lampau, yang menyimpan berbagai fitur yang dihasilkan. Penelitian ini bertujuan untuk mengetahui tingkatan lorong gua dengan menggunakan Sistem Informasi Geografis. Hasil kajian ini menunjukkan bahwa mulut Gua Banyu dan sekitarnya memiliki kenampakan yang mengelompok, dan pola yang berkembang di wilayah kajian berupa curvilinear passage yang didominasi sungai bawah tanah dan bidang perlapisan. Hasil dari tingkatan lorong gua dengan menggunakan software ArcGis diketahui dengan adanya 4 tingkatan lorong gua, yang menunjukkan arah lorong gua ke selatan.

\section{Ucapan Terima Kasih}

Kami ucapkan terima kasih kepada Unit Kegiatan Mahasiswa Pecinta Alam Jonggring Salaka (MPA JS) Universitas Negeri Malang atas kontribusinya dalam pengumpulan data baik berupa bantuan tenaga dari Anggota Biasa maupun peminjaman alat dari pengurus. Serta kami ucapkan terima kasih juga kepada Unit Kegiatan Mahasiswa IMPALA Universitas Brawijaya Malang dalam pelengkapan data sekunder,

\section{Daftar Rujukan}

Bemmelen, R.W. 1949. The Geology of Indonesia (2 vols). The Hague: Gtv Print Office

Ford D dan Williams P.2007. Karst Hydrogeology and Geomophology. England: British library

Ko, R.KT., 1997. Introduksi Karstologi dan Speleologi. Himpunan Kegiatan Speleologi Indonesia (HIKESPI). Tidak diterbitkan

Impala UB. 2013. Studi Potensi Kawasan Karst Inventarisasi dan Pendataan Ponor, Mata Air, dan Telaga/Danau Karst Serta Pemetaan Fauna Gua Dan Studi Masyarakat Di Desa Kedungsalam, Kecamatan Donomulyo, Kabupaten Malang. Laporan Akhir. Malang: Universitas Brawijaya

Jacoby, B.S. Peterson, E.W. Dogwiler T., Kostelnick J C.2011. Estimating the Timing of Cave Level Development with GIS. Speleogenesis \& Evolution of Karst Aquifers. 11, 52-61 (http://www.speleogenesis.info/content/)

Jacoby B S, Peterson E W., Kostelnick J C, and Dogwiler, T. 2013. Approaching Cave Level Identification with GIS: A Case Study of Carter Caves. Hindawi Publishing Corporation ISRN Geology Volume 2013, Article ID 160397. http://dx.doi.org/10.1155/2013/160397

Labib, M.A. 2016. Speleogeomorfologi Karst Kabupaten Donomulyo Kabupaten Malang. Thesis tidak diterbitkan. Yogyakarta: Universitas Gadjah Mada

MPA Jonggring Salaka, 2018. Eksplorasi Kawasan Karst Sendang Biru Kabupaten Malang. Yogyakarta: Cv Kosmojoyo Press

Palmer A. N. 1991. Origin and Morphology of Limestone Cave. Geological Society of America Bulletin, v 103, p. 1-21

Patrick dan Fischer. 1970. A Generalized k-Nearest Neighbor Rule. Information And Control 16, 128-152 (1970).

Piccini, L. 2011. Recent Developments on Morphometric Analysis of Karst Caves. 
Acta Carsologica 40/1, 43-52

Sjarifudin, M, Z, dan Hamidi, S. 1992. Geologi Lembar Blitar, Jawa. Bandung: Pusat Penelitian dan Pengembangan Geologi

Sugiyono. 2010. Metode Penelitan Pendidikan (Pendekatan Kuantitatif, Kualitatif, dan $R \& D)$. Bandung: Alfabeta

Tjia, H.D. 2013. Morphostructural Development of Gunungsewu Karst, Jawa Island Indonesian 